University of Nebraska - Lincoln

DigitalCommons@University of Nebraska - Lincoln

USDA National Wildlife Research Center - Staff Publications
U.S. Department of Agriculture: Animal and Plant Health Inspection Service

$11-12-2019$

\title{
FOOD HABITS OF COYOTES (CANIS LATRANS) IN THE VALLES CALDERA NATIONAL PRESERVE, NEW MEXICO
}

\author{
Suzanne J. Gifford \\ Utah State University, Logan \& National Wildlife Research Center \& Valles Caldera National Preserve, \\ s.gifford@aggiemail.usu.edu \\ Eric M. Gese \\ Utah State University, Logan \& National Wildlife Research Center \& Valles Caldera National Preserve \\ Robert R. Parmenter \\ Utah State University, Logan \& National Wildlife Research Center \& Valles Caldera National Preserve
}

Follow this and additional works at: https://digitalcommons.unl.edu/icwdm_usdanwrc

Part of the Natural Resources and Conservation Commons, Natural Resources Management and Policy Commons, Other Environmental Sciences Commons, Other Veterinary Medicine Commons, Population Biology Commons, Terrestrial and Aquatic Ecology Commons, Veterinary Infectious Diseases Commons, Veterinary Microbiology and Immunobiology Commons, Veterinary Preventive Medicine, Epidemiology, and Public Health Commons, and the Zoology Commons

Gifford, Suzanne J.; Gese, Eric M.; and Parmenter, Robert R., "FOOD HABITS OF COYOTES (CANIS LATRANS) IN THE VALLES CALDERA NATIONAL PRESERVE, NEW MEXICO" (2019). USDA National Wildlife Research Center - Staff Publications. 2345.

https://digitalcommons.unl.edu/icwdm_usdanwrc/2345

This Article is brought to you for free and open access by the U.S. Department of Agriculture: Animal and Plant Health Inspection Service at DigitalCommons@University of Nebraska - Lincoln. It has been accepted for inclusion in USDA National Wildlife Research Center - Staff Publications by an authorized administrator of DigitalCommons@University of Nebraska - Lincoln. 


\title{
FOOD HABITS OF COYOTES (CANIS LATRANS) IN THE VALLES CALDERA NATIONAL PRESERVE, NEW MEXICO
}

\author{
Suzanne J. Gifford, * Eric M. Gese, and Robert R. Parmenter \\ Department of Wildland Resources, Utah State University, Logan, UT 84322 (SJG) \\ United States Department of Agriculture, Wildlife Services, National Wildlife Research Center, Department of Wildland Resources, \\ Utah State University, Logan, UT 84322 (EMG) \\ Valles Caldera National Preserve, P.O. Box 359, Jemez Springs, NM 87025 (RRP) \\ *Correspondent: s.gifford@aggiemail.usu.edu
}

\begin{abstract}
Wildlife managers needed to understand coyote (Canis latrans) ecology in order to develop management plans on the nascent Valles Caldera National Preserve in northern New Mexico. Managers concerned about low elk (Cervus elaphus) recruitment had observed an increase in sightings of coyotes and observations of coyote predation on elk calves. Our objective was to identify and quantify coyote diet, and assess the temporal variation in coyote diet on the Valles Caldera National Preserve, particularly as related to elk calf consumption. We examined coyote food habits using 1,385 scats analyzed monthly from May 2005 to November 2008. The most frequent taxa were rodents (predominantly voles from the genus Microtus, and northern pocket gophers, Thomomys talpoides), elk, insects from the orders Orthoptera (grasshoppers and crickets) and Coleoptera (beetles), mountain cottontail rabbit (Sylvilagus nuttallii), and plant material (mainly grass). We detected rodent and elk in scats during all months of the study and were each present in $54 \%$ of scats overall. We identified elk remains in $43 \%$ of spring scats, $72 \%$ of winter scats, and $56 \%$ of fall scats. During summers, we could distinguish calf from adult elk hair: $8 \%$ of summer the scats contained adult elk hair and 39\% contained calf elk hair. The frequency of prey items varied significantly over most seasons and years, with notable exceptions being that elk did not vary among summers and winters, and rabbits were a consistent diet item through all seasons. The high frequency of elk in the coyote diet bears further study on the density of elk calves, the vulnerability of elk to predation, the nutritional impacts from the quality of forage available to elk, and the role of hunting and other mammalian predators in providing carcasses.
\end{abstract}

Resumen-Con el fin de elaborar planes de manejo para la recientemente establecida Valles Caldera National Preserve en el norte de Nuevo México, fue necesaria una mejor comprensión de la ecología del coyote (Canis latrans). Los administradores, preocupados por niveles bajos de reclutamiento de alces (Cervus elaphus), habían observado un aumento en los avistamientos de coyotes y en las observaciones de la depredación de las crías de alce por coyotes. Nuestro objetivo fue identificar y cuantificar la dieta de los coyotes e y evaluar su variación temporal en la Valles Caldera National Preserve, particularmente en lo referente al consumo de crías de alce. Para examinar los hábitos alimenticios de los coyotes, se examinó un total de 1,385 heces recolectadas mensualmente entre mayo de 2005 y noviembre de 2008. Los taxones más frecuentes fueron los roedores (predominantemente topillos del género Microtus y tuzas Thomomys talpoides), alces, insectos de los órdenes Orthoptera (saltamontes y grillos) y Coleoptera (escarabajos), conejo (Sylvilagus nuttallii) y material vegetal (principalmente pastos). Los roedores y alces fueron detectados en heces durante todos los meses del estudio, y cada uno estuvo presente en 54\% del total de heces. Se identificaron restos de alce en $43 \%$ de las heces en la primavera, $72 \%$ de las del invierno, y $56 \%$ de las del otoño. Durante los veranos se pudo diferenciar el pelo de las crías de las de los adultos: $8 \%$ de las heces de verano contenían pelo de alce adulto y $39 \%$ contenían pelo de cría de alce. La frecuencia del tipo de presas tuvo una variación significativa a lo largo de la mayoría de las estaciones y años, con excepción del alce, el cual no tuvo variación entre veranos e inviernos, y los conejos, que fueron un tipo de alimento consistente a lo largo de todas las estaciones. La alta frecuencia de alce en la dieta del coyote sugiere la necesidad de más estudios sobre la densidad de crías de alce, la vulnerabilidad del alce a la depredación, los impactos nutricionales de la calidad del forraje disponible al alce y el papel que juegan la caza y otros depredadores mamíferos en la provisión de cadáveres de alce. 
The interactions between predators and their prey depend on a broad range of ecological and environmental factors (Menge and Olson, 1990; Sinclair and Pech, 1996). Use of a particular prey species will depend on prey availability, climatic variables (temperature, precipitation, snow depth), nutritional status of the prey, age structure of the prey population, and prevalence of conspecific and intraguild competition for prey (Mech et al., 1991; Murray et al., 1997; Phillips and White, 2003). Coyotes (Canis latrans) are generalist and opportunistic predators and scavengers (Murie, 1940). Previous food habit analyses have shown that prey abundance both spatially and temporally (Bowyer et al., 1983; Hamlin et al., 1984; Richer et al., 2002; Prugh, 2005) influences coyote diet. In certain ecosystems, predation by coyotes was a major cause of mortality of neonatal ungulates (Barrett, 1984; Smith and Anderson, 1996; Ballard et al., 2001). The occurrence of ungulates in coyote diets might be related to coyote social status (Gese et al., 1996a), coyote group size (Bowen, 1981; Bowyer, 1987; Gese et al., 1988), alternate prey availability (Hamlin et al., 1984; Lingle, 2000), nutritional status of ungulates relative to the time of year (Gese and Grothe, 1995; Kunkel and Pletscher, 1999), and availability of carrion.

Our objective was to quantify and assess the temporal variation in coyote diet, particularly as related to elk (Cervus elaphus) calf consumption, on the Valles Caldera National Preserve, New Mexico (Valles Caldera NP). The Valles Caldera NP was a newly designated (2000) federal preserve with long-term natural resources management planning in progress. Revenues from elk hunts were critical to the financial sustainability of the Valles Caldera $\mathrm{NP}$, so managers were concerned about the sustainability of the high-density elk population in light of calf:cow ratios estimated to be the lowest in the state (New Mexico Department of Game and Fish, pers. comm.; Valles Caldera Trust, pers. comm.). These observations coincided with increased visibility of coyotes following the establishment of the Valles Caldera NP and cessation of coyote killing/harassment, and coyote predation events on elk calves observed by Valles Caldera NP staff and visitors. Scat analysis is a reliable noninvasive method for determining the diet components of coyotes (Murie, 1951; Ortega, 1987; Brillhart and Kaufman, 1995; ÁlvarezCastañeda and González-Quintero, 2005).

Materials and Methods-The Valles Caldera NP is a $360-\mathrm{km}^{2}$ volcanic caldera in north-central New Mexico characterized by large, grassland meadow valleys (approximately 2,600-2,800 m elevation), and forested mountains (approximately 2,800-3,400 m elevation). Parry's oatgrass (Danthonia parryi), Thurber fescue (Festuca thurberi), Arizona fescue (Festuca arizonica), pine dropseed (Blepharoneuron tricholepis), and Kentucky bluegrass (Poa pratensis) alliances dominated the meadows, with a diversity of sedges (Carex species) and rushes (Juncus species) in the wet meadow and riparian areas (Muldavin and Tonne, 2003). Mean annual precipitation was $640 \pm 9.7 \mathrm{~mm}(S D)$, predominantly in the form of monsoon rains (July and August) and winter snow (November through March; Western Regional Climate Center, http://www.wrcc.dri.edu/vallescaldera/). Mean July daily maximum and minimum temperatures were 25.5 and $5.5^{\circ} \mathrm{C}$, respectively; mean January daily maximum and minimum temperatures were 4.6 and $-16.5^{\circ} \mathrm{C}$, respectively (Valles Caldera Trust, pers. comm.). During the study (2005-2008), both summer precipitation and winter snowpack varied considerably, with the winter of 2005-2006 being exceptionally dry (Natural Resources Conservation Service, http:/ /www.wcc.nrcs.usda.gov/ nwcc $/$ site sitenum $=708 \&$ state $=\mathrm{nm}$ and Valles Caldera Trust, http://www.wrcc.dri.edu/vallescaldera/). The study site served as a concentrated breeding area for a high-density elk herd (New Mexico Department of Game and Fish, pers. comm.).

After initially clearing transects of all scats, we collected coyote scats on $25-40 \mathrm{~km}$ of lightly traveled gravel roads in the southeastern portion of the Valles Caldera NP once per week from May 2005 to November 2008 (43 months). We collected all scats from transects during each survey, ensuring scats collected would have been deposited since the previous collection. When snow conditions prevented collection from roads, we collected scats from cross-country ski and snowshoe trails in the same area. We froze scats $\left(-20^{\circ} \mathrm{C}\right)$ until analysis. We analyzed up to 42 scats per collection month; for months when we collected more than 42 scats, we randomly selected 40 scats for analysis. We ovendried scats at $60-70^{\circ} \mathrm{C}$ for a minimum of $24 \mathrm{~h}$ to kill potential parasites and bacteria (Colli and Williams, 1972). We identified diet items from scats by visual inspection and comparison to published keys (Glass, 1981; Jones and Manning, 1992; Moore et al., 1997; Martin et al., 2000), reference texts (Adorjan and Kolenosky, 1969; Gilbert et al., 1981; Gilbert, 2003; Elbroch, 2006), and reference collections (Museum of Southwestern Biology, Albuquerque, New Mexico, and Valles Caldera NP collections), and by consulting with experts. We identified birds and insects to class and order levels, respectively. We identified mammal remains to genus or, whenever possible, species level. We differentiated age of elk as calf (up to first molt at 4-5 months old) or adult (>4-5 months old) based on differences in hair and root diameter, and hair length and texture, using comparison to locally collected known material and consultation with experts. Our distinction was consistent with De Marinis and Asprea (2006).

We recorded the percentage of volume of diet items to the nearest $20 \%$ for each scat (Martin et al., 1946; Weaver and Hoffman, 1979). We calculated the relative volume for each month; volume totaled $100 \%$ across all prey types for pooled samples each month. For statistical comparisons, we grouped diet items by five predominant taxa: rodents, elk, insects, rabbits, and plants, and we compiled monthly scat calculations into four seasons per year. We defined seasons based on expected climactic, phenological, and food availability patterns: spring (March-May, characterized by snow melt, wind, and typically dry weather), summer (June-August, characterized by the monsoon rains, the highest temperatures, and the availability of insects and elk calves), fall (September-November, characterized by elk hunting season and therefore the availability of elk carcass remains), and winter (December-February, characterized by the coldest temperatures and deep snow in a typical year). We calculated frequency of occurrence as the proportion of scats during each time period containing $\geq 10 \%$ volume for each taxonomic group. We used contingency table 
TABLE 1-Total occurrence (and percentage of occurrence) of major food items found in 1,385 coyote scats, Valles Caldera National Preserve, New Mexico, 2005-2008. Other food items were detected in $<5 \%$ of coyote scats.

\begin{tabular}{lc}
\hline \hline Taxon & Occurrence total $(\%)$ \\
\hline Rodents & $746(54)$ \\
Elk & $741(54)$ \\
Insects & $231(17)$ \\
Rabbits & $175(13)$ \\
Plants & $455(33)$ \\
\hline
\end{tabular}

analysis ( $\mathrm{R}$ 3.3.2, R Foundation for Statistical Computing, Vienna, Austria) to evaluate the temporal variation in the frequency of occurrence of the five main taxa (Ciucci et al., 1996) between seasons within years, and between years by season.

RESULTS-We analyzed a total of 1,385 coyote scats from 15 seasons spanning 43 months. The most frequent taxa were rodents (predominantly voles from the genus Microtus and northern pocket gophers, Thomomys talpoides), elk (adult and calf), insects (Orthoptera and Coleoptera), rabbits (predominantly Sylvilagus nuttallii), and plants (predominantly grass; Table 1); these same taxa also consituted most of the volume of scats (Fig. 1). Birds, snakes, and additional mammal species were present in $<5 \%$ of scats.

Elk remains were present in coyote scats during all months of the study. The frequency of elk varied seasonally during all years of the study (Table 2). We observed two peaks in total elk consumption per year: one in early summer (June), which was principally calf elk, and a second in winter when young of the year could not be distinguished from adults (peaked during NovemberJanuary; Fig. 2a). The frequency of elk varied significantly among years for spring and fall seasons, but not for summers or winters (Table 2).

During 2005, 2007, and 2008, elk calf consumption was highest in June, followed by a lesser peak in September. In contrast, during 2006, calf consumption generally climbed through the summer and peaked in September (Fig. 2a). The amount of elk calf hair observed in scats was low or absent by October because most calves had completed the first molt and therefore their hair was no longer distinguishable from adult elk hair in scats. Elk was present in $47 \%$ of summer scats $(39 \%$ of summer scats contained calf elk) and $72 \%$ of winter scats.

Rodent remains often constituted $\geq 30 \%$ of the volume of scats (Fig. 2b). Rodent taxa included 11 genera within 5 families, with $82 \%$ of occurences of Rodentia being cricetids, and $92 \%$ of ocurrences of cricetids being voles. Vole remains were present in coyote scats in 42 of the 43 months of the study period. Northern pocket gophers (Thomomys talpoides) were consistently present in smaller proportions (14\% of occurences of Rodentia). Sciurid mammals were present during warmer months $(7 \%$ of occurences of Rodentia); we found prairie dog (Cynomys gunnisoni) remains in small amounts in all summers of the study, but they were not a major diet component. Rodent occurrence varied significantly between all seasons and years (Table 2). Rodents occurred in scats nearly twice as frequently during the low-snow 2005-2006 winter as during the 2006-2007 and 2007-2008 deep-snow winters (Table 3).

Lagomorph remains were nearly entirely mountain cottontail. Of 175 lagomorph occurrences, 174 were mountain cottontail rabbits and 1 was black-tailed jackrabbit (Lepus californicus), a species that rarely occurred on Valles Caldera NP but is common at lower elevations. During winter 2005-2006 we noted a prey

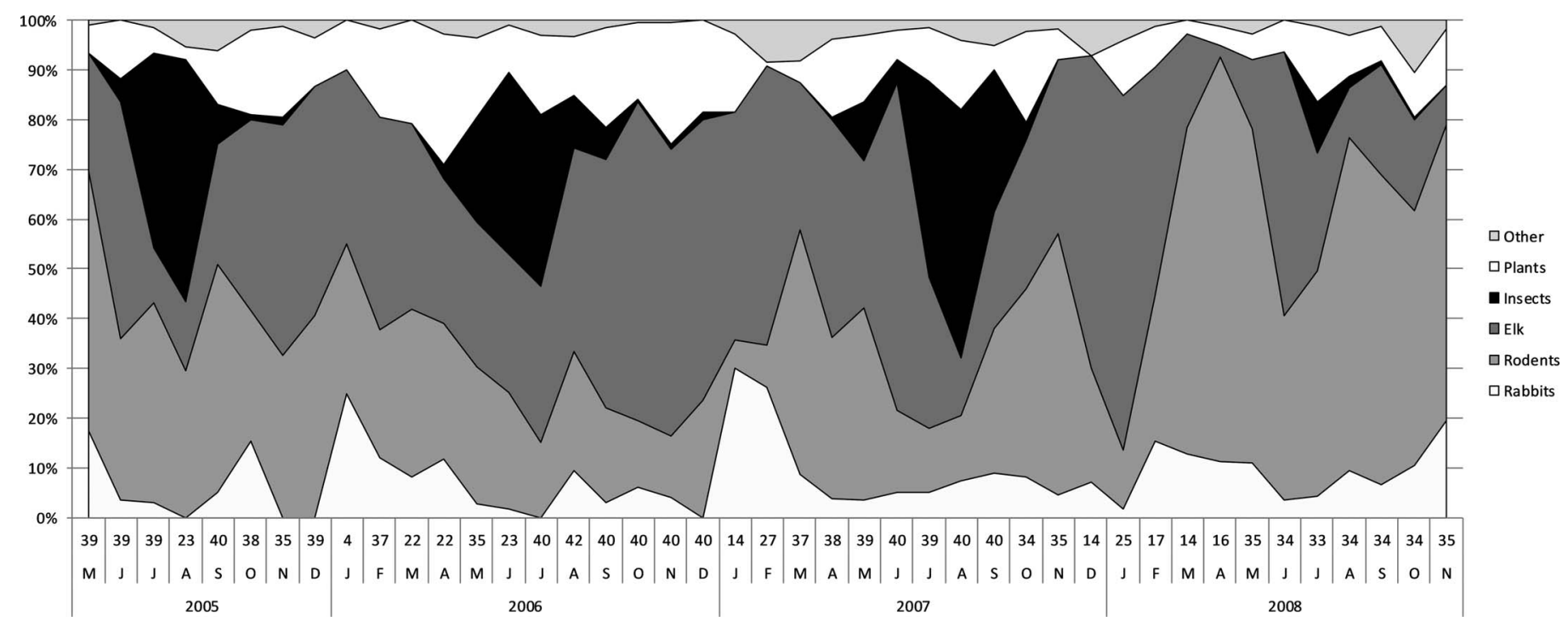

Fig. 1-Monthly volume of major food classes found in coyote scats $(n=1,385)$, Valles Caldera National Preserve, New Mexico, 2005-2008. Monthly sample size of scats examined is indicated above each month. 
TABLE 2-Results of contingency analysis comparing frequency of occurrence of five predominant taxa a) between years for each season and b) between seasons for each year, in coyote scats on the Valles Caldera National Preserve, New Mexico, 2005-2008.

\begin{tabular}{|c|c|c|c|c|c|c|c|c|c|c|c|c|}
\hline & & $\mathrm{df}$ & $\chi^{2}$ & $P$ & $\chi^{2}$ & $P$ & $\chi^{2}$ & $P$ & $\chi^{2}$ & $P$ & $\chi^{2}$ & $P$ \\
\hline & Spring & 3 & 29.758 & $<0.001$ & 17.317 & $<0.001$ & 19.802 & $<0.001$ & 11.946 & 0.008 & 28.833 & $<0.001$ \\
\hline & Summer & 3 & 55.922 & $<0.001$ & 6.622 & 0.085 & 34.232 & $<0.001$ & 6.426 & 0.964 & 16.412 & $<0.001$ \\
\hline & Fall & 3 & 63.250 & $<0.001$ & 59.562 & $<0.001$ & 13.604 & 0.003 & 12.295 & 0.006 & 14.704 & 0.002 \\
\hline \multicolumn{13}{|c|}{ b) Year } \\
\hline & 2005 & 2 & 9.086 & 0.011 & 6.292 & 0.043 & 43.032 & $<0.001$ & 14.993 & $<0.001$ & 16.337 & $<0.001$ \\
\hline & 2006 & 3 & 21.024 & $<0.001$ & 27.704 & $<0.001$ & 68.473 & $<0.001$ & 2.386 & 0.496 & 8.064 & 0.045 \\
\hline & 2007 & 3 & 39.885 & $<0.001$ & 17.700 & $<0.001$ & 83.428 & $<0.001$ & 4.264 & 0.234 & 1.557 & 0.669 \\
\hline & 2008 & 3 & 63.407 & $<0.001$ & 41.107 & $<0.001$ & 25.461 & $<0.001$ & 3.328 & 0.344 & 15.043 & 0.002 \\
\hline
\end{tabular}
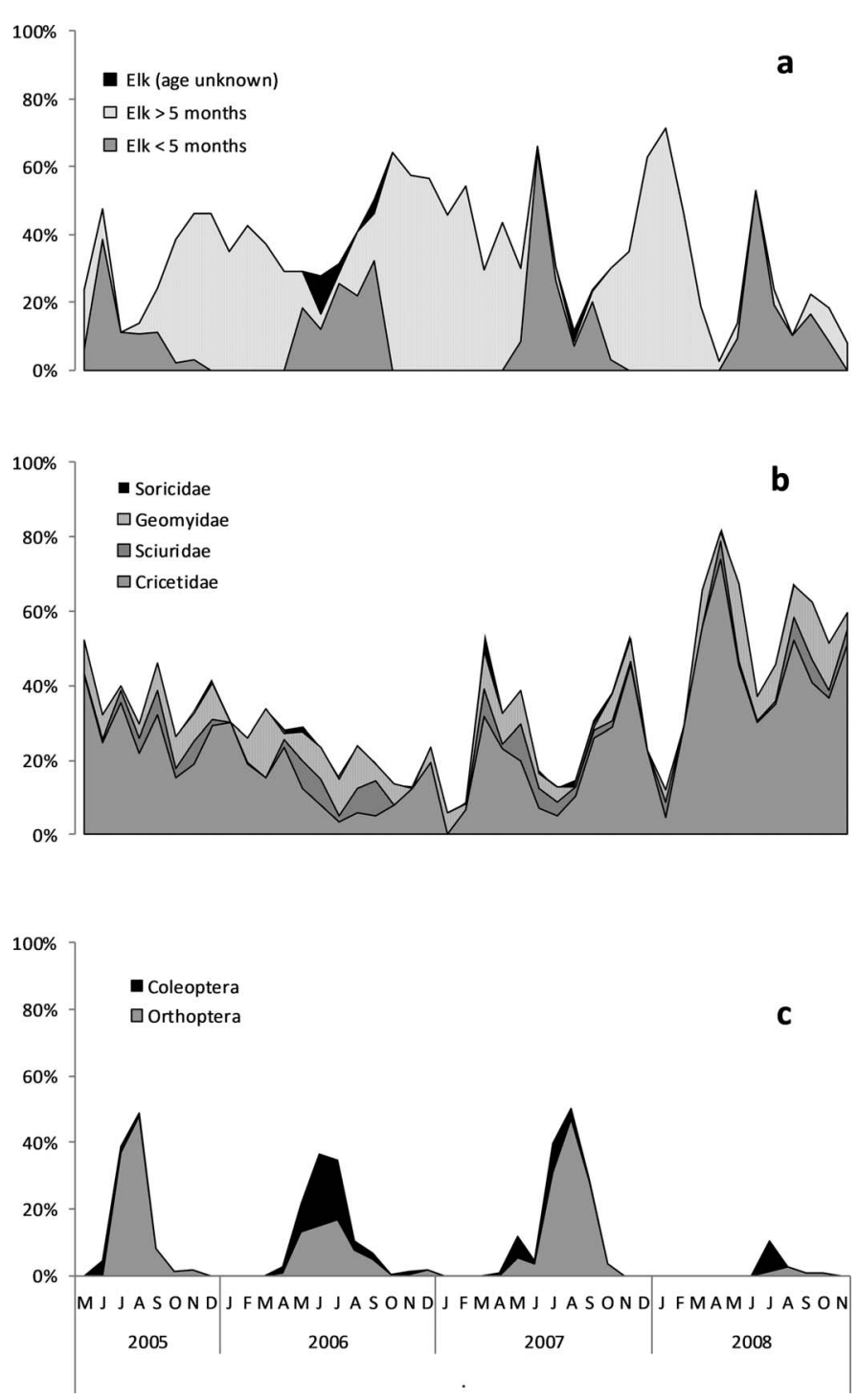

FIG. 2-Monthly volume of a) elk by age class, b) four families of Rodentia and Soricomorpha, and c) two orders of insects found in coyote scats, Valles Caldera National Preserve, New Mexico, 2005-2008. shift: vole consumption sharply declined and rabbit consumption reached its peak for the study. Seasonal variation in rabbit occurrence was only significant during 1 year of the study (in 2005); annual variation was significant for spring and fall seasons, but not for summers and winters (Table 2).

We detected pulses of insect consumption during the summer months (Fig. 2c). Coyotes on the Valles Caldera NP consumed insects almost exclusively from two orders, Coleoptera (beetles) and Orthoptera (grasshoppers and crickets), with the peak of coleopteran consumption occurring just prior to the peak of consumption of orthopterans during all four summers. The overall volume of insects in the diet appeared similar for summers 2005-2007, with insects occurring during 6 to 9 months per year, however, the composition of Coleoptera and Orthoptera varied (Fig. 2c). We observed a smaller and briefer pulse of insect consumption during the summer of 2008 than during the summers of 20052007, with insects only occurring during 4 months of 2008. We recorded very few orthopterans during the summer 2008, and the pulse of Coleoptera consumption occurred later than in the three preceding summers, peaking in July (compared with May or June for 20052007). The frequency of insects in scats varied seasonally for all years of the study and varied annually for spring, summer, and fall seasons (Table 2).

Plant remains were present in coyote scats during 42 months of the 43-month study (Fig. 1). Plants were generally $\leq 15 \%$ of the relative volume and predominantly consisted of grass (93\% of plant ocurrences were grass), with fewer conifer needles or cone pieces, and occassional seeds or leaves. The frequency of plants varied significantly annually, and plant frequency varied seasonally during 2 years of the study (Table 2 ).

Discussion-Elk was an important food item and, as with rodents, we detected it in coyote scats during all months of the study. At the time of our study, coyote 
TABLE 3-Percentage of occurrence by season of diet items in coyote scats on the Valles Caldera National Preserve, New Mexico, 2005-2008.

\begin{tabular}{lrccccc}
\hline \hline & $n$ & $\begin{array}{c}\text { Rodents } \\
(\%)\end{array}$ & $\begin{array}{c}\text { Elk } \\
(\%)\end{array}$ & $\begin{array}{c}\text { Insects } \\
(\%)\end{array}$ & $\begin{array}{c}\text { Rabbits } \\
(\%)\end{array}$ & $\begin{array}{c}\text { Plants } \\
(\%)\end{array}$ \\
\hline 2005 & & & & & & \\
Spring & 39 & 79 & 49 & 0 & 28 & 15 \\
Summer & 101 & 52 & 39 & 41 & 5 & 19 \\
Fall & 113 & 55 & 56 & 10 & 12 & 41 \\
2006 & & & & & & \\
Winter & 80 & 64 & 68 & 0 & 13 & 34 \\
Spring & 79 & 51 & 52 & 19 & 10 & 53 \\
Summer & 105 & 40 & 56 & 43 & 8 & 40 \\
Fall & 120 & 33 & 83 & 8 & 7 & 49 \\
2007 & & & & & & \\
Winter & 81 & 30 & 74 & 2 & 17 & 32 \\
Spring & 114 & 59 & 50 & 11 & 9 & 26 \\
Summer & 119 & 31 & 45 & 50 & 11 & 25 \\
Fall & 109 & 63 & 51 & 17 & 16 & 25 \\
2008 & & & & & & \\
Winter & 56 & 34 & 75 & 0 & 13 & 18 \\
Spring & 65 & 89 & 22 & 0 & 20 & 18 \\
Summer & 101 & 79 & 49 & 14 & 15 & 40 \\
Fall & 103 & 84 & 33 & 2 & 22 & 38 \\
\hline
\end{tabular}

persecution had recently ceased (in 2000), so coyotes may have shifted their activity patterns (Kitchen et al., 2000) and habitat use to overlap more with elk diurnal use of open meadow habitats (Gifford et al., 2017). Based on our field observations, coyote consumption of elk calves resulted from a combination of predation and scavenging. We observed coyote predation on elk calves and coyote scavenging of calves killed by other predators (golden eagle, Aquila chrysaetos; black bear, Ursus americanus; and cougar, Puma concolor) or killed by causes other than predation (e.g., stillborn, caught in fence; S.J.G., pers. observ.). We expected a high presence of calf remains in coyote scats collected during June and July; because our study took place in the concentrated calving area of a high-density elk herd, the coyotes we studied likely had access to more elk calves than coyotes studied in other locations. Given the high density of elk calves on Valles Caldera NP, the impact of predation on neonatal elk bears further evaluation. Bernal (2013) attributed mortality of 23 of $140(16 \%)$ radio-tagged elk calves to coyote predation.

By mid-July, calves would have survived the neonatal stage and would be much less vulnerable to predation (Smith and Anderson, 1996; Bernal, 2013). Therefore, we expected the presence of calf hair to diminish by mid-July of each year. However, calves occurred in coyote scats through August and September of each year, suggesting the Valles Caldera NP elk calves were vulnerable to coyote predation past the neonatal stage, which raises consideration of impairments such as nutritional deficiencies
(Bender et al., 2008), or the possibility that coyotes scavenged calves killed by other predators or calves that died from other causes during late summer.

The volume of calf hair in scats was greater in September each year than during the preceding summer months. We expected calves to be stronger and faster in September than in preceding months, so it is unlikely that direct coyote predation increased. Bull elk hunts began on Valles Caldera NP in early September. Although hunting season for calves and their dams did not begin until October each year, we observed that the presence of hunters in September immediately increased elk vigilance and decreased the amount of time elk spent in the open meadows. With adult and calf elk spending more time in the hiding cover of forests, we might expect them to be more susceptible to cougar predation. Bernal (2013) found during 2009-2011 that the mean age of radiotagged elk calves on Valles Caldera NP killed by cougars was 127.3 days (range, 5-244), whereas calves killed by coyotes or black bears averaged 8.0 days (range, 1-31) and 9.7 days (range, 1-37), respectively. Coyote scavenging of cougar-killed elk calves might therefore be a factor in the increase of elk calf hair in the September diets.

The frequency of elk in coyote scats did not vary significantly between summer seasons, but the timing of calf consumption was different during 2006 than during the other summers. During summers 2005, 2007, and 2008 , we documented a large spike in calf consumption in June, which quickly declined. During 2006, however, the amount of elk in the coyote diet generally increased through the summer, comprising $20-30 \%$ of the volume during July, August, and September (Fig. 2a). Bernal's (2013) latest documented coyote-caused mortality of a tagged elk calf on Valles Caldera NP during 2009-2011 was a 31-day-old calf; given the median birth dates he reported for calves, coyote-caused mortality would have ceased by early July, similar to Smith and Anderson's (1996) finding that all neonatal elk mortality occurred by 15 July in northwest Wyoming. Bernal's (2013) study occurred during years of average precipitation on Valles Caldera $\mathrm{NP}$, including average snow depths preceding and during the study; in contrast, during our study, summer 2006 followed an extreme low-snow year on Valles Caldera NP (Natural Resources Conservation Service, http://www.wcc. nrcs.usda.gov $/$ nwcc $/$ site? sitenum $=708 \&$ state $=$ nm). Elk on Valles Caldera NP were consistently in very good to excellent body condition going into winters per examination of organ fat of hunter-harvested elk (Valles Caldera Trust, pers. comm.). During winters with average snowfall, most elk migrated to adjacent lower-elevation winter ranges (Biggs, 2007), although some elk remained on Valles Caldera NP even during winters of average or above average snow depth (J. R. Biggs, pers. comm.). However, during low-snow winters, most of the elk herd stayed on Valles Caldera NP, where less desirable winter forage might have compromised elk nutritional status (Biggs, 2007). 
The crude protein in grasses on Valles Caldera NP was measured to be 2.4-4.2\% during January 2004 (R.R.P., pers. observ.), which is insufficient for elk to maintain their body mass through the winter (Cook, 2002). Weber et al. (1984) reported that according to body weight and blood serum indicators, elk using the lower-elevation winter range were on a higher dietary level than elk wintering on Valles Caldera NP, and they suggested that the observed difference in body weights of cow elk based on wintering sites could affect calf survival. Thorne et al. (1976) reported that cow elk that lost weight during winter months produced lower-birth-weight calves than cows that did not lose weight, and that chances of calf survival declined substantially as birth weight declined. We suggest that the dry 2005-2006 winter negatively influenced the health and vulnerability of the elk calves born the subsequent spring, with compromised nutrition because of failure to migrate to lower-elevation winter range as a possible mechanism. Determining whether the vulnerability of calves was because of cow health during gestation or lactation, the timing of parturition, the nutritional quality of summer forage for calves, or additional stressors such as human disturbance would require further investigation.

The total volume of elk in coyote scats increased through the fall months, as expected based on the boon of gut piles from hunter-harvested elk. Elk hunts ceased by the end of November each year. Elk hair was present in winter scats in a consistently high amount despite contrasting severity of the winters during the study period. The high volume and frequency of elk in winter scats raise the question of how coyotes accessed such a large prey item. Previous impairments of the elk (e.g., by snow, injury, fences, poor nutritional condition, or separation from the herd) were a factor in previously documented cases of coyote predation on adult elk, even when coyotes were in a group (Murie, 1935; Gese and Grothe, 1995). The winters on Valles Caldera NP are relatively mild compared with the low temperatures and deep snow in the northern portion of North American elk distribution, and lower-elevation winter range is within close proximity of Valles Caldera NP, so we did not expect winter-killed elk to be available to coyotes. Although not quantified, we made many observations of elk carcasses with wounds suggesting that hunters had fatally injured, but not retrieved, the elk. Therefore, the source of elk in coyote winter diets could be persistence of remains of hunter-harvested and hunter-wounded elk through winter months or scavenging of elk killed by cougars, vehicles, or other causes. The effect of the elk hunts in providing elk remains to coyotes on the Valles Caldera NP in winter bears further study.

Elk was the most common item in coyote scats (Carrera et al., 2008) in an area of Arizona and New Mexico with sympatric Mexican wolf recolonization. In the similar Greater Yellowstone Ecosystem, Murie (1935) reported elk calf in only $3.1 \%$ of coyote scats in the Jackson Hole area of Wyoming, while Murie (1940) reported elk calf in only $3.3 \%$ of coyote scats in Yellowstone National Park, Wyoming. In a recent study, Dowd and Gese (2012) still found only $5.8-14.6 \%$ of coyote scats in the Jackson Hole area had elk, with the highest frequency of elk in winter $(14.6 \%)$ likely as a result of coyotes scavenging wolf-killed elk. Wigglesworth et al. (2001) found cervid (mostly elk) remains in $28.3 \%$ of coyote scats in early summer and $37.7 \%$ in winter from an undeveloped area in the Jackson Hole valley.

Voles were a main year-round food of coyotes on the Valles Caldera NP during the entire study period. Voles are a reliable prey source because they are active near the ground surface diurnally and nocturnally year-round. Microtus montanus was common in the grasslands on the Valles Caldera NP; Microtus longicaudus and Myodes gapperi occurred only in higher-elevation conifer forests, and were presumably less available to coyotes using our study area. Vole populations have an irruptive nature (Krebs, 2013) depending on the availability of vegetation (Negus et al., 1977). Cricetids were more frequent in scats during the 2005-2006 low-snow winter than during the two deepsnow winters, consistent with previous studies of the influence of snow depth on coyote predation on small mammals. Wells and Bekoff (1982) found greater coyote capture success of voles in shallow snow. Similarly, Gese et al. (1996b) found a clear advantage to coyotes at low (515-cm) snow depth rather than no snow, with decreased small mammal detection rates and capture attempts as snow depth increased to $>15 \mathrm{~cm}$. Hamlin et al. (1984) concluded that in north-central Montana, continuous snow depth of at least $30 \mathrm{~cm}$ for at least part of the winter was important for vole winter breeding and insulation from severe cold temperatures. Coyote consumption of voles on the Valles Caldera NP was highest during spring and fall 2008, following two consecutive snowy winters. Other rodent families occurred much less frequently in coyote diets.

Rabbit species identified in scats reflected live species observations on the Valles Caldera NP. While observers have commonly noted $S$. nuttallii, there has only been one documented observation of L. californicus on the Valles Caldera NP during 2003-2016 (R.R.P., pers. observ.). We found a fairly consistent, low frequency of rabbits in the coyote scats. A noteworthy peak in rabbit consumption occurred in winter 2006-2007, when mountain cottontail rabbit was present in $50 \%$ of scats. A large storm covered the ground with deep snow, which ostensibly made cottontails easier for coyotes to catch; concomitantly, rodent consumption was at its lowest frequency of the 43month study.

The frequency of prey in the family Soricidae is likely underestimated. Because of their small size, the bones and teeth of these shrews were more likely to have been digested by coyotes or missed during our laboratory analysis (as per Weaver and Hoffman, 1979). 
The annual variation of insects in coyote scats by spring, summer, and fall seasons was associated with the timing and intensity of insect population irruptions. In summer 2008, the pulse of insect consumption was noticeably smaller than during the other summers of the study by both volume (Fig. 2c) and frequency measures; rodents increased to their highest volume and frequency in scats during this time. Possible mechanisms were a low insect (particularly Orthopteran) population, or an increase in the vole population during 2008.

Mule deer (Odocoileus hemionus) was found in remarkably few of the scats (2 of 1,385), despite a consistent but very small mule deer population fawning in the study area, suggesting negligible coyote predation or scavenging on adult or juvenile mule deer during the study period. Cattle remains were also conspicuously missing from coyote scats. Livestock grazing began in early June each year because of the high elevation, so most calves were a few months old before livestock operators transported them to the Valles Caldera NP. To date, no observers have noted predator killing of domestic cattle on the Valles Caldera NP.

The dearth of fruit in comparison to coyote diets in much of their range (e.g., Andelt et al., 1987; Brillhart and Kaufman, 1995; Neale and Sacks, 2001) is a reflection of the lack of fruit-producing vegetation in our study area, similar to Murie's (1935) observations in Jackson Hole, Wyoming. As undigested material, grass volume is overrepresented relative to the remains of other items consumed. Grass consumption by wild and domestic canids is commonly documented and is considered to be a normal behavior of healthy individuals (Bjone et al., 2007); however, the reason for grass consumption remains unknown (Sueda et al., 2008; McKenzie et al., 2010).

The Valles Caldera ecosystem was dynamic in terms of seasonal and annual changes in climate and vegetative phenology, with coyote diet fluctuating across seasons and years, presumably tracking changes in prey availability and vulnerability, as well as changes in coyote biological needs (Andelt et al., 1987; Randa et al., 2009). Despite the presence of many minor diet items, coyote diet consisted of the same five predominant groups across all 4 years of diet analysis. Winter snow appeared to influence the vulnerability of the main prey species through detection and capture probability or nutritional influences (Gese and Grothe, 1995; Gese et al., 1996a, 1996b; Prugh, 2005). Diet components identified were entirely naturally occurring items, despite a significant and growing human presence on the Valles Caldera NP. Our results both reinforce the coyote's reputation as a generalist, opportunistic predator on the Valles Caldera NP and illustrate the coyote's dietary plasticity in a high-elevation environment. While we confirmed a significant presence of calf and adult elk in the coyote diet, coyote consumption of elk outside of the neonatal time frame calls for examination of the vulnerability of elk to predation, including elk nutritional status relative to annual climate variation, habitat quality, and population density, as well as the role of other predators and human hunters in providing carcasses for coyotes.

This project was funded by the Valles Caldera Trust, Jemez Springs, New Mexico; the United States Department of Agriculture, Forest Service, Rocky Mountain Research Station, Albuquerque, New Mexico; and the United States Department of Agriculture, Wildlife Services, National Wildlife Research Center, Logan, Utah. We thank M. Peyton, N. vonHedemann, M. Chipault, J. Kinzer, G. Kaufman, and J. Biggs for field and laboratory assistance. D. Ramsey and R. O'Donnell reviewed earlier versions of the manuscript. S. Cobbold did the Spanish translation of the abstract. S. Dunn, A. Gutheim, M. Padgett, R. Seeley, M. Salisbury, K. Montgomery, D. Serabia, S. Gilmore, E. Welty, and A. Roberts made valuable contributions to this effort.

\section{Literature Cited}

Adorjan, A. S., and G. B. Kolenosky. 1969. A manual for the identification of hairs of selected Ontario mammals. Ontario Department of Lands and Forests Wildlife Report Number 90:1-64.

Álvarez-Castañeda, S. T., And T. GonzÁlez-Quintero. 2005. Winter-spring food habits of an island population of coyote Canis latrans in Baja California, Mexico. Journal of Arid Environments 60:397-404.

Andelt, W. F., J. G. Kie, F. F. Knowlton, and K. Cardwell. 1987. Variation in coyote diets associated with season and successional changes in vegetation. Journal of Wildlife Management 51:273-277.

Ballard, W. B., D. Lutz, T. W. Keegan, L. H. Carpenter, and J. C. DEVos, JR. 2001. Deer-predator relationships: a review of recent North American studies with emphasis on mule and black-tailed deer. Wildlife Society Bulletin 29:99-115.

Barrett, M. W. 1984. Movements, habitat use, and predation on pronghorn fawns in Alberta. Journal of Wildlife Management 48:542-550.

Bender, L. C., J. G. Cook, R. C. Cook, and P. B. Hall. 2008. Relations between nutritional condition and survival of North American elk Cervus elaphus. Wildlife Biology 14:70-80. https://doi.org/10.2981/0909-6396(2008)14[70:RBNCAS]2. $0 . \mathrm{CO} ; 2$

Bernal, L. J. 2013. Investigations into possible factors affecting the recruitment of Rocky Mountain elk (Cervus elaphus) on the Valles Caldera National Preserve. M.S. thesis, Texas Tech University, Lubbock.

Biggs, J. R. 2007. Patch use dynamics of Rocky Mountain elk (Cervus elaphus nelsoni) following the Cerro Grande fire, Jemez Mountains, New Mexico. Ph.D. dissertation, New Mexico State University, Las Cruces.

BJone, S. J., W. Y. Brown, and I. R. Price. 2007. Grass eating patterns in the domestic dog, Canis familiaris. Recent Advances in Animal Nutrition in Australia 16:45-49.

Bowen, W. D. 1981. Variation in coyote social organization: the influence of prey size. Canadian Journal of Zoology 59:639652. 
BowYER, T. R. 1987. Coyote group size relative to predation on mule deer. Mammalia 51:515-526.

Bowyer, T. R., S. A. McKenna, and M. E. Shea. 1983. Seasonal changes in coyote food habits as determined by fecal analysis. American Midland Naturalist 109:266-273.

Brillhart, D. E., AND D. W. Kaufman. 1995. Spatial and seasonal variation in prey use by coyotes in north-central Kansas. Southwestern Naturalist 40:160-166.

Carrera, R., W. Ballard, P. Gipson, B. T. Kelly, P. R. Krausman, M. C. Wallace, C. Villalobos, and D. B. Webster. 2008. Comparison of Mexican wolf and coyote diets in Arizona and New Mexico. Journal of Wildlife Management 72:376381.

Ciucci, P., L. Boitani, E. R. Pelliccioni, M. Roco, and I. Guy. 1996. A comparison of scat-analysis methods to assess the diet of the wolf Canis lupus. Wildlife Biology 2:37-48.

Colli, C. W., AND J. F. Williams. 1972. Influence of temperature on the infectivity of eggs of Echinococcus granulosus in laboratory rodents. Journal of Parasitology 58:422-426.

Cook, J. G. 2002. Nutrition and food. Pages 259-349 in North American elk: ecology and management (R. E. McCabe, technical editor). Smithsonian Institution Press, Washington, D.C.

De Marinis, A. M., And A. Asprea. 2006. Hair identification key of wild and domestic ungulates from southern Europe. Wildlife Biology 12:305-320.

Dowd, J. L. B., AND E. M. GesE. 2012. Seasonal variation of coyote diet in northwestern Wyoming: implications for dietary overlap with Canada lynx? Northwest Science 86:289-299.

Elbroch, M. 2006. Animal skulls: a guide to North American species. Stackpole Books, Mechanicsburg, Pennsylvania.

Gese, E. M., AND S. Grothe. 1995. Analysis of coyote predation on deer and elk during winter in Yellowstone National Park, Wyoming. American Midland Naturalist 133:36-43.

Gese, E. M., O. J. Rongstad, and W. R. Mytton. 1988. Relationship between coyote group size and diet in southwestern Colorado. Journal of Wildlife Management 52:647-653.

Gese, E. M., R. L. Ruff, and R. L. Crabtree. 1996a. Foraging ecology of coyotes (Canis latrans): the influence of extrinsic factors and a dominance hierarchy. Canadian Journal of Zoology 74:769-783.

Gese, E. M., R. L. Ruff, and R. L. CRabtree. 1996b. Intrinsic and extrinsic factors influencing coyote predation of small mammals in Yellowstone National Park. Canadian Journal of Zoology 74:784-797.

Gifford, S. G., E. M. Gese, and R. R. Parmenter. 2017. Space use and social ecology of coyotes (Canis latrans) in a highelevation ecosystem: relative stability in a changing environment. Journal of Ethology 35:37-49.

Gilbert, B. M. 2003. Mammalian osteology. Missouri Archaeological Society, Columbia.

Gilbert, B. M., L. D. Martin, and H. G. Savage. 1981. Avian osteology. B. Miles Gilbert, Laramie, Wyoming.

Glass, B. P. 1981. A key to the skulls of North American mammals. Second edition. Oklahoma State University, Stillwater.

Hamlin, K. L., S. J. Riley, D. Pyrah, A. R. Dood, and R. J. Mackie. 1984. Relationships among mule deer fawn mortality, coyotes, and alternate prey species during summer. Journal of Wildlife Management 48:489-499.

Jones, J. K., JR., AND R. W. MANning. 1992. Illustrated key to skulls of genera of North American land mammals. Texas Tech University Press, Lubbock.

Kitchen, A. M., E. M. Gese, And E. R. Schauster. 2000. Changes in coyote activity patterns due to reduced exposure to human persecution. Canadian Journal of Zoology 78:853-857.

Krebs, C. J. 2013. Population fluctuations in rodents. University of Chicago Press, Chicago, Illinois.

Kunkel, K., and D. H. Pletscher. 1999. Species-specific population dynamics of cervids in a multipredator ecosystem. Journal of Wildlife Management 63:1082-1093.

Lingle, S. 2000. Seasonal variation in coyote feeding behavior and mortality of white-tailed deer and mule deer. Canadian Journal of Zoology 78:85-99.

Martin, A. C., R. H. Gensch, and C. P. Brown. 1946. Alternative methods in upland gamebird food analysis. Journal of Wildlife Management 10:8-12.

Martin, R., R. Pine, and A. DeBlase. 2000. A manual of mammalogy with keys to families of the world. Third edition. McGraw-Hill, New York.

McKenzie, S. J., W. Y. Brown, And I. R. Price. 2010. Reduction in grass eating behaviours in the domestic dog, Canis familiaris, in response to a mild gastrointestinal disturbance. Applied Animal Behaviour Science 123:51-55.

Mech, L. D., M. E. Nelson, and R. E. McRoberts. 1991. Effects of maternal and grandmaternal nutrition on deer mass and vulnerability to wolf predation. Journal of Mammalogy 72:146-151.

Menge, B. A., And A. M. Olson. 1990. Role of scale and environmental factors on community structure. Trends in Ecology and Evolution 5:52-57.

Moore, T. D., L. E. Spence, and C. E. Dugnolle. 1997. Identification of the dorsal guard hairs of some mammals of Wyoming. Wyoming Game and Fish Department, Cheyenne.

Muldavin, E., AND P. Tonne. 2003. A vegetation survey and preliminary ecological assessment of Valles Caldera National Preserve, New Mexico. Final report, University of New Mexico, Albuquerque.

Murie, A. 1940. Ecology of the coyote in the Yellowstone. Fauna of the National Parks of the United States Bulletin No. 4. United States Government Printing Office, Washington, D.C.

Murie, A. 1951. Coyote food habits on a southwestern cattle range. Journal of Mammalogy 32:291-295.

Murie, O. J. 1935. Food habits of the coyote in Jackson Hole, Wyoming. Circular 362. United States Department of Agriculture, Washington, D.C.

Murray, D. L., J. R. Cary, and L. B. Keith. 1997. Interactive effects of sublethal nematodes and nutritional status on snowshoe hare vulnerability to predation. Journal of Animal Ecology 66:250-264.

Neale, J. C. C., And B. N. Sacks. 2001. Food habits and space use of gray foxes in relation to sympatric coyotes and bobcats. Canadian Journal of Zoology 79:1794-1800.

Negus, N. C., P. J. Berger, and L. G. Forslund. 1977. Reproductive strategy of Microtus montanus. Journal of Mammalogy 58:347-353.

Ortega, J. C. 1987. Coyote food habits in southeastern Arizona. Southwestern Naturalist 32:152-155.

Phillips, G. E., ANd G. C. White. 2003. Pronghorn population response to coyote control: modeling and management. Wildlife Society Bulletin 31:1162-1175. 
Prugh, L. R. 2005. Coyote prey selection and community stability during a decline in food supply. Oikos 110:253-264.

Randa, L. A., D. M. Cooper, P. L. Meserve, And J. A. Yunger. 2009. Prey switching of sympatric canids in response to variable prey abundance. Journal of Mammalogy 90:594-603.

Richer, M., M. Crête, and J.-P. Ouellet. 2002. The low performance of forest versus rural coyotes in northeastern North America: inequality between presence and availability of prey. Ecoscience 9:44-45.

Sinclair, A. R. E., AND R. P. PECh. 1996. Density dependence, stochasticity, compensation and predator regulation. Oikos 75:164-173.

Smith, B. L., And S. H. Anderson. 1996. Patterns of neonatal mortality of elk in northwest Wyoming. Canadian Journal of Zoology 74:1229-1237.

SuedA, K. L. C., B. L. Hart, AND K. D. Cliff. 2008. Characterisation of plant eating in dogs. Applied Animal Behaviour Science 111:120-132.

Thorne. E. T., R. E. Dean, and W. G. Hepworth. 1976. Nutrition during gestation in relation to successful reproduction in elk. Journal of Wildlife Management 40:330-335.

Weaver, J. L., and S. W. Hoffman. 1979. Differential detectability of rodents in coyote scats. Journal of Wildlife Management 43:783-786.

Weber, B. J., M. L. Wolfe, G. C. White, and M. M. Rowland. 1984. Physiologic response of elk to differences in winter range quality. Journal of Wildlife Management 48:248-253.

Wells, M. C., And M. Bekoff. 1982. Predation by wild coyotes: behavioral and ecological analyses. Journal of Mammalogy 63:118-127.

Wigglesworth, R. R., N. McClennen, S. H. Anderson, and D. G. WAснов. 2001. Comparison of coyote diets between two areas of Jackson Hole, Wyoming. Intermountain Journal of Sciences 6:355-367.

Submitted 12 September 2016. Accepted 12 November 2019. Associate Editor was Celia López-González. 